\title{
Formal party organisation and informal relations in African parties: evidence from Ghana*
}

\author{
ANJA OsEI \\ University of Konstanz, Department of Politics and Management, \\ P.O. Box 9o, 78457 Konstanz, Germany \\ Email: anja.osei@uni-konstanz.de
}

A B S T R A C T

It is often assumed that political parties in Africa have only weak formal structures and are instead dominated by informal, personalised networks. This paper seeks to challenge this view by presenting a much more nuanced picture of intra-party dynamics. Based on unique survey data from Ghana, it is shown how formal and informal party structures co-exist and interact at the national and constituency level. Because informal relationships are not directly observable and difficult to study, the paper employs a social network approach to map the personal interactions between the Members of the 6th Parliament of Ghana and their respective parties. It is found that the local party organisation plays a strong role in both of the major parties NDC (National Democratic Congress) and NPP (New Patriotic Party). There are, however, also differences between the parties. At the national level, the NDC is strongly centralised and dominated by its national executives. The NPP, in contrast, has an informal power center located in the Ashanti Region. Ethno-regional factions play only a minor role in both parties. By demonstrating that the relative importance of informal relations varies even between parties in the same country, the paper contributes to a better understanding of the variation in party organisation across Africa.

* Funding for this research was provided by the Excellence Initiative of the German Research Foundation (DFG). The author wishes to thank the Center for Democratic Development (CDD) in Accra/Ghana for the generous assistance; special thanks go to Professor Emmanuel Gyimah-Boadi, Franklin Oduro, Mohammed Awal and Regina Oforiwaa-Amanfo. Furthermore, I thank the editorial team of the Journal of Modern African Studies and two anonymous reviewers for their helpful comments on an earlier version of the paper. 
Scientific interest in African political parties began to rise in the late 1990s. At first, there was only limited empirical research, and the field was characterised by 'sweeping generalizations derived from rather cursory observations' (Basedau et al. 2007: 11). African parties were commonly described in terms of their deficits: weak links to civil society groups, no convincing programmatic appeals, and weak or non-existent formal party structures. In addition, most of them were believed to be dominated by ethnic loyalties and clientelistic relationships (Erdmann 2004). Although recent studies have helped to paint a more differentiated picture of the role of ethnicity (Basedau et al. 2011), clientelism (Lindberg \& Morrison 2008) and programmatic appeals (Bleck \& van de Walle 2011), questions pertaining to the internal organisation of parties have remained virtually neglected in the scientific literature. Some time ago, Carbone (2007: 10) summarised the situation as follows:

Party organisations are often so weak that, in a sense, there appears to be little to observe. Party organs are frequently on paper, but not a reality. They are extremely centralised and respond to personalist and informal practices that are difficult to pin down.

Little has changed since then. With a few exceptions (Darracq 2008; Bob-Milliar 2012), there is still a lack of studies on party organisation. There are, however, some publications that provide a certain amount of information on party organisation as part of the investigation of broader topics such as party system institutionalisation (Osei 2013; Riedl 2014), party-voter linkages (Osei 2012), economic development (Pitcher 2012), and the transformation of opposition movements into political parties (LeBas 2011). What this literature suggests is that there might be great variation in the strength of party organisations both across and within countries (see also LeBas 2011: 22). In the case of Tanzania, Kelsall (2003: 6o) argues that party membership is 'disproportionately composed of young men looking for patronage, rather than of dues-paying members'. Pitcher (2012: 117) describes party politics in Zambia in a similar fashion, but she also finds that parties in Mozambique (especially Frelimo and to a lesser extent Renamo) appear to be better organised, more disciplined and more national in character (Pitcher 2012: 161-6). The African National Congress (ANC) has a solid party structure and is comparatively 'more accountable to its members and the general public' (Pitcher 2012: 208). Similarly, Darracq (2008: $5^{89}$ ), who studies the local organisation 
of the ANC, claims that the party conforms to the mass party ideal-type, with active branches and a certain level of members' influence on decision-making within the party.

This paper seeks to further contribute to this field by presenting new insights into the relationship between formal and informal party structures in Ghana. With regard to the two major parties NDC (National Democratic Congress) and NPP (New Patriotic Party), two questions will be answered. First, are the two major parties dominated by formal party structures or by informal, personalised networks? Second, are there informal ethnic or regional party factions? To answer these questions, the paper employs a social network approach which maps the structure of personal interactions between the Members of the 6th Parliament of Ghana (MPs) and their respective parties at the national, regional and constituency levels. The paper proceeds as follows: the second section situates the research question of this paper in the contemporary literature on political parties and identifies the lack of information on the relative importance of formal and informal party structures as one of the major research gaps. The third section gives an overview over the nature of political competition in Ghana. The fourth section explains the methodological approach and operationalises the research question. The fifth section is devoted to the empirical analysis, and the final section draws some conclusions.

PARTY ORGANISATION IN AFRICA IN COMPARATIVE PERSPECTIVE

\section{Party types and classifications}

Parties can be classified according to a variety of criteria, for example their formal organisation, programmatic commitments, social origin, functional performance or electoral strategies (Gunther \& Diamond 2003; Sartori 2005). Organisational classifications - and especially the notion of the mass party with its extended formal party apparatus, strong ideology and mass membership - have featured prominently in the political parties literature. For a long time it has been commonplace 'to think of parties, both empirically and normatively, in terms of the European mass party of integration' (Müller \& Katz 1997: 172; see also Erdmann 2004). Over the last decades, challenges to this dominant model arose from two different directions. On the one hand, parties in Western Europe are undergoing profound changes as they are losing members and become less strict in their ideological orientations (see Katz \& Mair 1995). On the other hand, most of the political parties 
created in the new democracies around the world after 1990 have relatively weak formal structures and ideologies (Carothers 20o6: 6-7). Thus, the political parties of the late 2oth century can no longer 'be captured using classic party typologies developed a century earlier' (Gunther \& Diamond 2003: 168). Similarly, Erdmann (2004: 63) claims that party research has had a very pronounced Western European bias and that the 'concepts based on the European mass party model ... failed to cope with African realities'. Drawing on the work of Gunther \& Diamond (2003), he then characterises the majority of African parties as congress parties (Erdmann 2004; see also Erdmann \& Basedau 2008). Congress parties are coalitions of ethnic groups that gain votes through clientelistic loyalities (Erdmann 2004: 79). Typically, they lack an extensive organisational apparatus and an elaborated party programme (Gunther \& Diamond 2003: 183).

Although Erdmann (2004) insists on the necessity to incorporate African parties into general typologies with worldwide applicability, he makes a further important point by emphasising the importance of informality: While research on Western countries has largely ignored informal party structures, they are absolutely central for the understanding of African parties (Erdmann 2004: 74-5). He thus links political party research to the 'lively debate ... about the relative importance of formal and informal institutions' (Bratton 2007: 96) that persists among the scholars of African politics. The next section will briefly review the main arguments of this debate, after which a framework for analysis will be developed.

\section{Informality in the local and the national party}

Like many other concepts in the social sciences, 'informality' is difficult to define and has often been treated as a residual category (Misztal 1999: 17; Helmke \& Levitsky 2004: 728). The term has been used to describe a 'relaxed, casual or non-ceremonial approach to conformity with formal rules, dress codes and procedures' (Mistzal 1999: 17). At the same time, it can refer to actions behind the scenes that result in 'favouritism, nepotism, and patronage and are thus perceived as a threat to fair and just treatment' (Mistzal 1999: 18). For the sake of clarity, this paper employs the definition set out by Helmke \& Levitsky (2004: 727), which views informal institutions as socially shared rules, usually unwritten, that are created, communicated and enforced outside of officially sanctioned channels. By contrast, formal institutions are 'rules and procedures that are created, communicated, and enforced through channels widely 
accepted as official'. The latter includes state institutions, but also the official rules that govern organisations such as political parties (Helmke \& Levitsky 2004: 727).

Informality can complement and even replace formal organisation, or it may be in conflict with it (Helmke \& Levitsky 2004: 728-9). Most scholars of African politics consider informal and formal institutions to be inextricably interlinked. This is most clearly expressed in the term 'neopatrimonialism', which is frequently used to describe African politics. In neopatrimonial systems, formal rules coexist and interact with informal, clientelistic networks (Erdmann \& Engel 2007). Such patronclient relationships have continued to shape party competition even after the wave of democratisation that took place in the 1990 os (see e.g. Bratton \& van de Walle 1997; Chabal \& Daloz 1999), and voters are still believed to exchange their electoral support for material favours and benefits.

In the context of political parties, two levels of informal relations can be distinguished. First, clientelistic relationships may exist between parties and voters, and second, there may be clientelistic networks within the party. In other words, local candidates must entertain clients, and the national party must integrate these local big men (Allen 1995: 304).

The clientelistic relationship between parties and voters has attracted considerable scholarly attention (see for example Lindberg 2003; Beck 2008; Koter 2013). In order to gain votes, parties incorporate local big men as 'shortcuts' to the rural population. In exchange for access to state patronage or individual benefits, these local power brokers urge their followers to support a certain political party. Under a formal multiparty system, however, various factors determine the concrete form of these arrangements. Intermediaries must not only be available but also powerful enough to influence voters (Koter 2013). Different categories of big men - ranging from chiefs to religious leaders, elders, wealthy businessmen, and other influential local figures - may have varying degrees of influence on voters. Furthermore, the nature of the party system, the number of parties, and the existence of ethnic or regional strongholds all play a role. Whatever concrete forms local clientelistic arrangements take, they are no automatic guarantee of votes, as voters may have their own reasons to vote with the chief or not (Baldwin 2013). As a consequence, it is unlikely that informal relationships will completely replace local party organisation; instead, the two systems generally interact with each other in various ways. In the simplest form of interaction, the party and the local big man have only a strategic link. 
These relationships do not interfere much with the local party and are open to renegotiation: if the respective candidate fails to deliver the promised benefits, whether personal or communal, the big man can withdraw his support. A second possibility is the integration of local big men into the formal party structure, either from 'above' or from 'below'. For example, as a part of its electoral strategy, the NDC in Ghana has sought to convince locally influential people and opinion leaders to stand as parliamentary candidates (Osei 2012: 155). ${ }^{1}$ This 'integration from above' has sparked unrest in the local party organisation because these candidates have been imposed without primary elections being held (see Daddieh \& Bob-Milliar 2012: 212). Alternatively, primaries can facilitate the integration of big men from below. Examples can be found in the Ghanaian NPP, where candidates have set up competing clientelistic networks within the local party to secure their nomination (see CODEO 2005: 25). In this way, a local big man with deep pockets can try to secure himself a seat in parliament and thereby extend his influence in the community even further. What can be clearly seen in these examples is that formal and informal relationships coexist, but that there are also possible tensions between them. In the 'integration from above' version, formal procedures of decisionmaking are violated in order to win popular support through informal influence. In 'integration from below', a formal contest exists but is distorted by informal clientelistic networks.

Informal networks, however, exist not only on the constituency level, but also in the national party. MPs are usually confronted with all kinds of demands from voters, such as the paying of school fees, funeral costs and electricity bills (Lindberg 2003). To fulfil these demands, it is necessary for the chains of clientelism to extend upwards as well: the higher the position in party and government, the more likely is the access to resources that can be distributed to local followers. In other words, the chances of re-election at the constituency level increase with the career advancement in the national party or government. Each MP wants to be a minister, and many ministers dream about being the next president. Especially in Ghana, where half of the ministers are chosen from the ranks of parliamentarians, a network of contacts and supporters within the party is a necessary asset. The struggle for the (always limited) number of posts and positions can thus lead to factional confrontations within the party, such as attempts to influence the party's strategy or policy, to gain access to patronage, or to represent local, regional or group interests (Zariski 1960: 33; Boucek 2009). A high degree of clientelistic factionalism is typical for congress parties, which are by definition composed of a 
coalition of ethnic groups (Gunther \& Diamond 2003: 184; Erdmann 2004: 72; Köllner \& Basedau 2005: 20). Factions built on clientelism are typically short-lived and variable, but also inherently competitive (Boucek 2009; Bob-Milliar 2012). This is not necessarily a problem, because to a certain degree 'all parties consist of coalitions of political actors who pursue their individual interests' (Köllner \& Basedau 2005: 5 ). When managed by an effective leadership, competitive factionalism can even provide a structure for internal power-sharing and conflict resolution (Boucek 2009: 479). However, it can also have negative consequences: it may undermine the cohesion and effectiveness of political parties and lead to personnel decisions that are based not on merit but on factional affiliations (Köllner \& Basedau 2005: 13). As at the local level, we can see that the relationship between formal party structures and informal factions can be complementary as well as conflictive (see also Köllner \& Basedau 2005: 14).

\section{Analysing formality and informality}

The previous section has shown that formal and informal structures can be present in varying proportions at both the local and the national level. Moreover, at both levels, these processes are inextricably linked and interact in complex ways. A major problem with the literature is, however, a certain tendency of overgeneralisation. Most of the information that we have on informality comes from qualitative case studies and thick descriptions. This is a suitable and indispensable approach to the investigation of African politics. It still has one major shortcoming: it does not produce data that are readily comparable across parties, countries or even regions. As a result, we can say with certainty that informality plays a role in African parties, but we cannot say how much of it is actually there. The question of 'how much' is an important one, as the literature suggests that there are differences between regions, countries and individual parties. Taking an extreme position, Carbone (2007) suggests that formal party organisation plays almost no role and that nearly all relationships are informal, whereas the work of LeBas (2011), Pitcher (2012), and others indicates that the strength of formal organisation varies widely. Even if we accept that most African parties belong to the type of the congress party, it would still be useful to gather comparative knowledge on the organisational variance across the continent. Such knowledge would not only contribute to a better understanding of African party politics, but also lay the foundation for more fine-grained classifications. 
This paper wants to take a first step in this direction. The comparative measurement of party organisation is in itself already a difficult task (Janda 1983), not to mention the fact that most of the indicators that are suggested in the literature (Janda 1983; see also Appleton \& Ward 1995) are simply unavailable for most African parties. Studying informal relations, which are not directly observable, is even more demanding. The paper therefore employs a social network approach to measure the comparative importance of formal and informal relations. For analytical reasons, this will be done on two levels: the constituency level and the national level. In addition, social network analysis is a very useful tool for detecting the presence of ethno-regional factions. Before the method is described in more detail in the fourth section, the next section will give an overview about party competition in Ghana.

\section{Overview}

Two major parties have dominated the political scene in Ghana since the reintroduction of multiparty politics in 1992: the National Democratic Congress (NDC) and the New Patriotic Party (NPP). Some smaller parties exist, but none of them has had any serious electoral impact.

The NDC emerged out of the Provisional National Defense Council (PNDC) of the former military ruler Jerry John Rawlings. When pressure for democratisation grew in the early 199os, Rawlings announced the return to multipartyism, but carefully managed the transition. The NDC served as the vehicle for his presidential ambitions and ensured political liberalisation without any transfer of power. It took until the year 2000 before the opposition NPP garnered its first victories in presidential and parliamentary elections. Under President John Agyekum Kufuor, the NPP held on to power for two electoral terms. Since then, each election has been closely fought. In 2008, the presidential candidates of the two major parties ran a neck-and-neck race that ended in a narrow victory for the NDC candidate, John Evans Atta-Mills. AttaMills died in 2012, but his vice president John Dramani Mahama, who was nominated as the party's candidate, secured another NDC victory. The opposition NPP challenged the election results, claiming major fraud, and filed a petition before the Supreme Court; however, the court dismissed the opposition's claims in August 2013. 
Party organisation, voting patterns and the role of money in politics

Ghanaian party law places a strong emphasis on the national character of political parties. It not only proscribes all particularistic parties, but also demands a nationwide organisational presence (see Boafo-Arthur 2003: 221). Although no ethnic parties exist in Ghana (Elischer 2013), both the NPP and the NDC have major regional strongholds. The Ashanti and Eastern Regions have always been in the tight grip of the NPP. Other Akan-populated regions (Brong Ahafo, Central and Western Regions) have oscillated between the parties. The NDC's major stronghold is the Volta Region, but it has also always swept the three northern regions. These regional strengths notwithstanding, both parties are well organised on the ground and possess a network of party branches across the entire country. The organisational structure is more or less the same for both parties: the smallest unit is at the level of the polling station ${ }^{2}$ and features - at least nominally - an executive committee consisting of a chairman and vice chairman, a party secretary, an organiser and a treasurer. This basic structure is replicated at the constituency, regional and national levels, but at the higher levels more functions are added (for example, organisers for women and youth).

Despite the strong organisational presence on the ground, both parties have deficits in intra-party democracy, accountability and communication. Irregularities frequently occur at all levels of the political process. Many scholars have commented on the fact that Ghanaian elections - although generally considered to be free and fair-are still expensive endeavours (Lindberg 2003; Nugent 2007; Daddieh \& BobMilliar 2012): constituents have to be visited, chiefs have to be greeted, and contributions to various causes have to be made (Nugent 2007: 261). MPs must also attend to individual needs (such as the paying of school fees or funeral expenses) to signify their willingness to 'take care of their people' (Lindberg 2003: 124). The great importance of wealth means that candidates without adequate financial means are directly disqualified (Daddieh \& Bob-Miliar 2012: 211). What is true for MPs is also true for presidential candidates: aspirants 'have to spend liberally in order to secure nomination in the first place' (Nugent 2007: 261). A prominent example is Alan 'Cash' Kyerematen, who spent enormous sums in his quest to be nominated as the NPP's flag-bearer in 2007. Despite his efforts to buy the votes of the delegates, he finally lost to the eventual presidential candidate Akuffo-Addo. His story also sheds light on the internal factional struggles for posts and positions. Not only did Kyerematen have significant 
financial means at his disposal, but he also had the support of former President Kufuor. The fact that he did not ultimately win can be explained in the context of an ongoing struggle between two competing factions in the party. In both the NPP and the NDC, factional struggles play a role in determining nominations and positions. The basic contours of these dynamics are detailed briefly below.

\section{Factionalism in the NPP}

The NPP's historical roots date back to the pre-independence era. The party claims the heritage of the so-called Busia-Danquah tradition, which began with the UGCG (United Gold Coast Convention), the first political party in what was later to become Ghana. The core characteristics of the UGCC - its liberal political orientation, its rather elitist social nature, and its strong support base among the Akan in southern Ghana - have lived on in various successor organisations. Two Akan subgroups (namely, the Ashanti, also called Asante, and the Akyem) have struggled for supremacy within the Busia-Danquah political system. ${ }^{3}$ Today, this conflict is reflected in what are called the Danquah faction and the Busia faction. Joseph Boakye (J.B.) Danquah, one of the founding fathers of the UGCC, was not only a member of the highly educated elite from the south of the country, but also the brother of Nana Ofori Atta I, the chief of the Akyem Abuakwa in the Eastern Region. Danquah later played an important role in the opposition to the socialist programmes developed under Ghana's first president, Kwame Nkrumah. After Nkrumah's expulsion in a military coup in 1964, Kofi Brefa Busia, a Bono, became the president of the Second Republic. His time in office was overshadowed by growing tensions between the Ashanti and the Ewe, and Busia was eventually ousted in another military coup led by General Acheampong. In 1979, Ghana returned to civilian rule. The Third Republic saw a manifestation of the factional divide in the Busia-Danquah tradition in the form of two competing parties: the Busia-faction PFP (Popular Front Party) featured a rather elitist political style and had a narrow base in the Ashanti region, whereas the Danquahfaction UNC (United National Convention) included many of those who rejected the power monopoly claimed by politicians from the Ashanti and Brong-Ahafo regions (Bob-Milliar 2012: 579). The elections of 1979 were finally won by Hilla Limann, a northerner in the tradition of Nkrumahism. After only two years, the Third Republic ended abruptly with the military coup led by Rawlings. The long ban on political parties under the PNDC regime apparently assuaged the factional struggles 
in the Busia-Danquah tradition. When party competition was revived in 1992, the NPP was quickly formed out of the already existing DanquahBusia Memorial Club. At first, it served as an umbrella for all opposition groups (Elischer 2013: 144) and sought to rid itself of its predominantly Akan image. In 1992, Adu Boahen, a history professor, was chosen as the party's candidate for the presidential election. Boahen, who belonged to the Danquah faction (Bob-Milliar 2012: 579), lost the election against Rawlings and was replaced as the presidential candidate by Kufuor in 1996. Kufuor came from a royal Ashanti family and had close ties to the Asantehene, the highest traditional authority of the Ashanti (Agyeman Duah 2003: 5). Kufuor's leadership style was ethnically rather inclusive (Elischer 2013: 156). At the same time, however, the Busia faction consolidated its power and monopolised all key sectors of the state apparatus (Bob-Milliar 2012: $5^{81}$; see also McCaskie 2009: 476 ). These moves did not go unchallenged. Already in the party primaries of 1998, Nana Akuffo-Addo announced his ambition to be the presidential candidate but lost the primary election to Kufuor. AkuffoAddo is an Akyem royal from the Eastern Region; furthermore, as a nephew of both J.B. Danquah and William Ofori-Atta, he was particularly well suited to return the leadership of the NPP to the control of the Danquah faction. As McCaskie (2009: 465) notes, Kufuor and AkuffoAddo were 'similar in many respects but different in one crucial way. ... Akufo-Addo's appeal as NPP leader was precisely that he was not Asante.' Akuffo-Addo's time finally came in the presidential primaries of 2007. Kufuor had served two terms as president of the republic and was not standing for election again. Factionalism was in full effect. There were 17 candidates, but Kufuor secretly threw his weight behind the candidacy of Alan Kyeremateng, an Asante with royal roots and close ties to the Asantehene. Akuffo-Addo ultimately emerged as the winner, but the rift between the factions became noticeable at the grassroots level, where some Kyerematen supporters voted independently (Bob-Milliar 201 2: 582-3). Factionalism thus contributed to the electoral defeat of the NPP in 2008 (Bob-Milliar 201 2: 583 ). The fact that the NPP lost the presidential and parliamentary elections again in 2012 has sparked discussions about the political future of Akuffo-Addo as well as about leadership issues in the party more generally. Concerns have been raised that the NPP could risk losing the 2016 election due to the rivalry between the Asante and the Akyem in the party. 4 Against this background the nomination of the northerner Mahamudu Bawumia as Akuffo-Addo's running mate can also be interpreted as an attempt to overcome the Akan dominance in the party and to better integrate 
especially the Muslim communities. 5 On several occasions, party officials have denied the existence of factions or downplayed their destructive potential. ${ }^{6}$ How deep this antagonism actually runs thus remains unclear.

\section{Factionalism in the NDC}

In the NDC, power struggles have revolved less around regional and ethnic divisions than around the charismatic personality of the party's founder, J.J. Rawlings. Its predecessor organisation, the PNDC, was a mixture of diverse groups, and in 1992, the NDC leadership incorporated all major ethnicities (Elischer 2013: 150). In the early years of the party, Rawlings was very dominant. His appointment as the NDC presidential candidate was unopposed in 1992 and 1996, but factionalism began to arise as his second term as president drew to a close. Two factions emerged: a pro-Rawlings faction, and a reformist faction that sought the party's renewal. This conflict escalated at a party congress held in Swedru in 1998 when Rawlings declared John-Evans Atta-Mills as his successor. Atta-Mills, an ethnic Fante from the Central Region, was largely unknown in the party. He seemed to be a good choice with regard to integrating the old left-wing Nkrumahist circles into the NDC and to winning more votes in the Central Region (Bob-Milliar 2012: 586-7). A candidate so completely dependent on Rawlings would also present no obstacle to Mrs Rawlings' future ambitions (Bob-Milliar 2012: 586). Not everyone in the party was happy with Atta-Mills' nomination. After the Swedru declaration, a splinter group broke away and formed the National Reform Party (NRP); however, this party has remained largely unsuccessful in national elections. Other reformists stayed in the party but continued to challenge the status quo. Their main concern was the overwhelming power that had been placed in the hands of Rawlings. For a few years, the power of the factions was relatively balanced (Bob-Milliar 2012: 589). At the party congress in 2002, the reformist wing triumphed (Elischer 2013: 165 ), but in 2005 , the Rawlings faction won back most of the powerful positions. Although the party was able to present a united face in the 2008 elections, the internal dynamics grew increasingly complicated. Atta-Mills' ailing health became a matter of concern, and his relationship with Rawlings soured. Allegedly, Rawlings sought to abandon him even before the 2008 election, but Atta-Mills had been able to build his own network of supporters. He was backed by the party reformists who sought to depersonalise politics, but also by the so-called 'Fante 
Confederacy', a coalition of influential Fante in the NDC (Bob-Milliar 2012: 590-1). Rawlings and his wife felt increasingly sidelined, even though some of their loyalists were elected to high party positions in 2010. The contest for the flagbearership in 2011 finally revealed the state of the NDC's changing power relations: Atta-Mills won with more than $90 \%$ of the delegates' votes, while Mrs Rawlings garnered a meagre $3 \cdot 1 \%$.

The dynamics changed again when Atta-Mills died in 2012 and was succeeded by Vice President Mahama, an ethnic Gonja from the Northern Region. After Hilla Limann, president of the Third Republic from 1979-81, Mahama was the second Ghanaian head of state to originate from the country's underprivileged north. This was a remarkable achievement, but it added another possible cleavage to the NDC's factionalism. Although Rawlings' continued harsh criticism of both the Atta-Mills and Mahama administrations has isolated him within the party, the Ghanaian press has speculated on the existence of at least three factions: the Volta Caucus in the traditional stronghold of the party, the Volta Region; the Fante Confederacy, consisting of Atta-Mills' former supporters (mainly stemming from the Central Region); and, finally, the so-called Gonja Octopus, a patronage network surrounding the president that promotes the interests of politicians from Mahama's home region. 7 As in the case of the NPP, the press has commented widely on the internal affairs of the NDC. The Ghanaian press is free and vibrant, but also tends to be sensationseeking, and therefore it can be difficult to separate facts from speculation. It cannot be ruled out that the factional dynamics in the NDC are more complex than the simple threeway-cleavage suggested in the media. There might also be more historical patterns, for example an ethnically heterogeneous network of older PNDC cadres who might consider themselves as 'first comers' against 'new comers' like Mahama and the late president Mills, who joined the NDC later and no comparably deep roots in the party network. In this regard, the role of former president Rawlings is an interesting but controversial question. Possibly, he still exerts an amount of influence on the Volta caucus, but similar to the NPP it is difficult to separate facts from speculation.

OPERATIONALISATION AND D A T A

The discussion of political competition in Ghana has clearly shown that formal and informal processes exist in both parties. As has been argued 
above, a quantifiable approach is necessary to determine the relative strength of formal and informal politics. For the empirical analysis, the two research questions outlined in the Introduction can now be formulated in a more specific way:

(1a) What is the relative proportion of informal and formal contacts at the constituency level?

(1b) Are the parties at the national level dominated by informal or formal relationships?

(2) Can a structure of subgroups be detected that coincides with the party factions that are assumed to exist in the NPP and NDC, respectively?

To answer these questions, the paper at hand combines case-based knowledge with a social network analysis that allows us to map the relationships between political actors. The data collection took place in close collaboration with the CDD (Center for Democratic Development) Ghana between June and August 2013. Members of the current Ghanaian legislature were interviewed using a standardised questionnaire; 253 of the 275 MPs (92\%) participated in the study. For this paper, MPs who did not belong to either the NPP or NDC were excluded from the analysis. Furthermore, although 253 MPs participated in the study, not all of them answered the questions that are of interest for this paper. ${ }^{8}$ Thus, we were left with 154 NDC-MPs and 121 NPP-MPs for whom we also had basic sociometric data such as gender and regional origin.

In order to obtain data on their personal relationships, the MPs were asked to name the people with whom they discussed important political decisions in (a) their constituency and (b) in their party. ${ }^{9}$ Using this method, we obtained data on the ego network of each MP. An ego network consists of a focal point (in this case, the MP) and his or her alters, meaning the people with whom he or she is in contact (see Figure 1).

For each MP, two ego networks were created: his or her contacts (a) at the constituency level and (b) at the party level. At the constituency level, each MP had a unique network of contacts, and there was no overlap between the alters. The total number of alters was 8oo. In order to answer Question 1, these alters were grouped into a number of categories, which were then coded as formal or informal contacts. A constituency chairman, for example, occupies a formal position in the party hierarchy and was therefore coded as a formal contact, whereas chiefs or religious leaders were coded as informal. The 


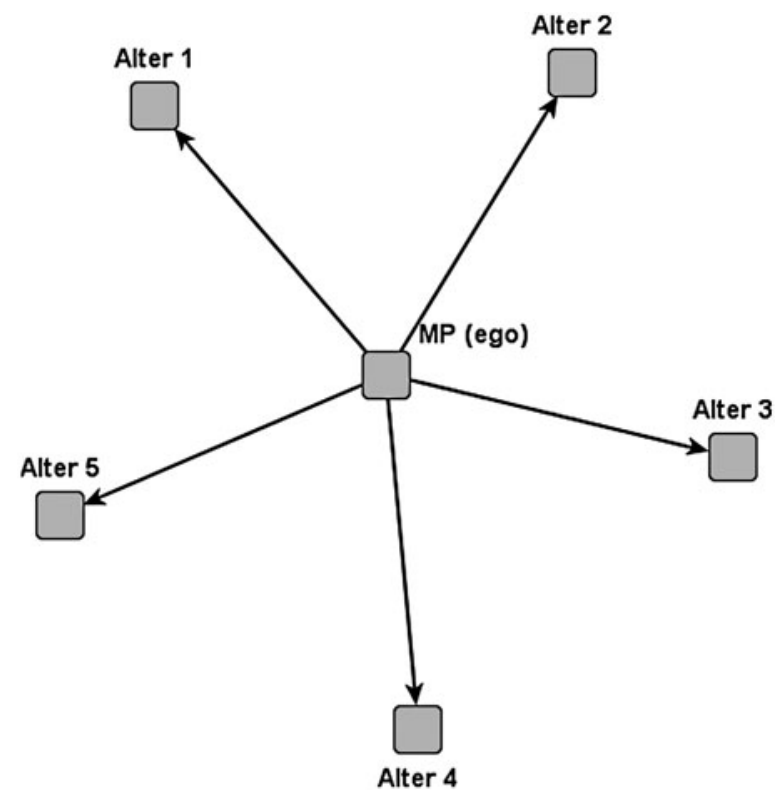

Figure 1 Ego network

frequencies with which certain groups of actors appeared in the ego networks allowed us to measure the relative strength of formal and informal relationships by using descriptive statistics. The results are described in the next section.

At the party level, all alters belong to the same population - the respective party. It is therefore possible to construct two interconnected networks of relationships, one for the NPP and one for the NDC. These networks can be further analysed using the techniques of social network analysis (see below). For this paper, all calculations were performed using UCINET (Borgatti et al. 2002). In addition, visone (Brandes \& Wagner 2004) was used for the visualisation of the networks shown in Figures 1-9. Social networks consist of nodes (the actors) and ties (the relationships between actors). The NPP network has 287 nodes and 483 ties, while the NDC network has 328 nodes and 572 ties. The analyses for Questions $1 \mathrm{a}$ and $1 \mathrm{~b}$ were performed on the basis of these party networks. For Question 2, measures of network centrality were used to describe the position of individual nodes in the network. There are many different concepts of centrality that can be applied to a wide range of questions (see Borgatti et al. 2013: 163-80). For the purpose of this paper, the analysis was restricted to degree centrality 


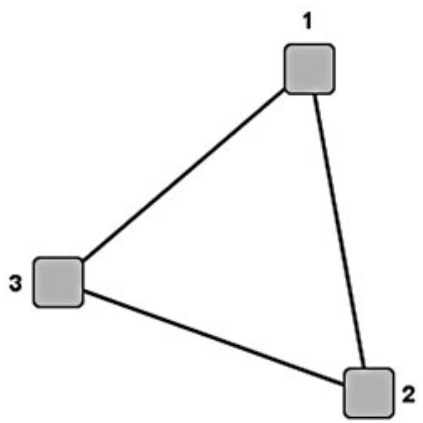

Figure 2 3-clique

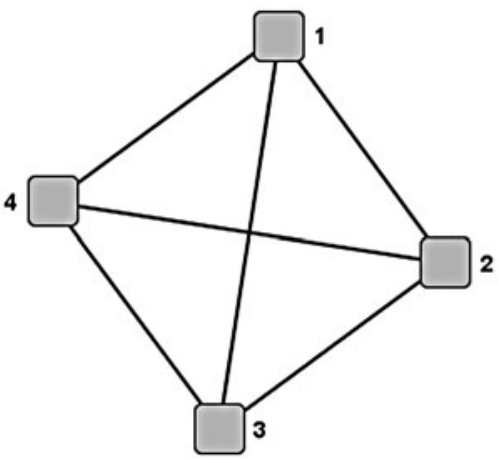

Figure 3 4-clique

and betweenness centrality. Degree centrality reflects the number of ties that a node receives (in-degree) or the number of ties that a node sends out to others (out-degree). Betweenness centrality measures how often a given node lies on the shortest paths between node pairs (Borgatti et al. 2013: 174). Nodes with a high betweenness score are usually powerful actors, as they are able to control the flows through the network.

Question 2 will be answered through an analysis of the subgroup structure of the networks. Subgroups are denser parts of the network that have more internal interactions than interactions with the rest of the network. Actors within such cohesive subgroups tend to share norms and patterns of behaviour (Borgatti et al. 2012: 183). Among the many different concepts of subgroups, the idea of the 'clique', which is used in this paper, is the most restrictive. A clique is a maximally complete sub-graph in which each node is adjacent to the others. For 
example, Figure 2 depicts a 3-clique with three members and Figure 3 depicts a 4-clique with four members.

Actors can be members of more than one clique. As a consequence, cliques tend to overlap, especially in large networks. UCINET automatically analyses patterns of clique overlap in order to obtain greater insight into the subgroup structure. At the clique level, this produces information on how many actors the cliques have in common (clique-byclique co-membership), and on the actor level, we gain an understanding of how many cliques a pair of actors has in common (actor-by-actor co-membership). This paper concentrates on the structure of actor comembership, which is visualised in Figures 6 and 7 . In these figures, the link strength indicates the number of cliques the actors have in common-the darker the line, the stronger the relationship. For Figures 8 and 9, only links with a value greater than 1 are included, meaning that these actors have at least two cliques in common. In other words, these sociograms show only actors who have extremely tight connections to each other. Finally, having identified the subgroup structure of the network, we are interested in whether the members of these cliques share other attributes - in our case, regional origin. As detailed above, the major cleavage in the NPP is believed to run between the Ashanti and the Akyem; in the NDC, there is a presumed three-way cleavage between the Volta Caucus, the Fante Confederacy and the Dagomba Octopus. Unfortunately, information on ethnic origin is only available for some of the actors. To solve this problem, regional origin can be used as a proxy: in the case of the Ashanti and the Akyem, the Ashanti and Eastern Regions, respectively; the Volta Region for the Volta Caucus; the Central Region for the Fante Confederacy; and the northern regions for the Dagomba Octopus. ${ }^{10}$ This approach has certain shortcomings, to be sure, since none of the regions is completely ethnically homogeneous, but it still provides a degree of insight into inner-party dynamics. To determine whether people from the same region are more likely to have a relationship, QAP (Quadratic Assignment Procedure) correlations were used. QAP correlations test the association between two networks (for more on this subject, see Borgatti et al. 2013: 125-33). ${ }^{11}$ In our case, one of these is the party network, in which actors either have a link (coded 1) or have no link (coded $\mathrm{o}$ ). The second matrix is produced by transforming the categorical attribute 'region' into a matrix of similarity: if actors are from the same region, they are coded 1 , while actors from different regions are coded o. In the first step, the QAP algorithm computes Pearson's correlation between corresponding cells of the two data matrices. In the 
second step, it randomly permutes rows and columns. This step is repeated a large number of times in order to compute the proportion of times that a random measure is greater than or equal to the observed measure calculated in step $1 .{ }^{12}$ As with conventional statistics, a low proportion (below $0 \cdot 05$ ) suggests that the relationship between the matrices is unlikely to have occurred by chance. The results are reported in Table V.

Finally, a general caveat should be noted. The data used in this paper are part of a broader project on the social characteristics and social relationships of African Members of Parliament, and MPs are therefore overrepresented in the party network. Because this is equally true for both parties, the differences that are found in the network structure can still shed light on the general relationship between formality and informality. It should also be noted that the networks reflect the intra-party dynamics at the moment of data collection. Later events such as party elections or changes in leadership cannot be taken into account.

EMPIRICAL ANALYSIS: FORMALAND INFORMAL NETWORKS

\section{Constituency level}

At the constituency level, the interviewed MPs mentioned three groups of people as important contacts: (1) the local party organisation, (2) local government representatives, such as Assemblymen/women or District Chief Executives, ${ }^{13}$ and (3) a range of contacts that can be considered to be informal. This final category includes people such as chiefs, opinion leaders, religious leaders and many others. Informal contacts were a bit more frequent in the NPP, but the difference between parties in this regard is relatively small and statistically not significant (Pearson's chi-square $4 \cdot 68, \mathrm{p}>0 \cdot 0_{5}$; see Table I). There are also no statistically significant differences in the regional distribution of formal or informal contacts (not shown).

With regard to the formal party, the constituency chairman, the constituency secretary and the constituency organiser were the most frequently named contacts. The category 'other' includes people like the vice chairman, the communication officer for the constituency, and personal assistants (see Figure 4).

Among the informal contacts, chiefs were by far the most frequently mentioned category, followed by opinion leaders, religious leaders and elders (see Figure 5). There was also a large residual category of people who were only named a few times, some even only once. This 
category contains people such as schoolteachers, police officers and local businesspeople. In general, there was some variation in the composition of the ego networks: some MPs listed only formal contacts, while others mentioned only informal contacts. However, in most ego networks, people from both categories appeared.

Although the results show that local intermediaries are important, they also reveal the strong role of the local party organisation.

\section{Comparing the party networks: The role of national executives}

Both party networks (composed of the ego networks of the party MPs) are densely interconnected. Table II presents the relative proportions of MPs and national, regional and local party functionaries in the NPP and NDC networks.

Due to the nature of the collected data, MPs feature prominently. It can be seen, however, that the NDC-MPs have slightly more frequent contacts with national functionaries than the NPP-MPs. While these differences are small, the analysis of network centrality offers more insightful details. Table III lists the 10 people with the highest number of incoming connections (in-degrees) in the NPP. To facilitate comparisons between the two party networks, the normalised degree centrality is also given. ${ }^{14}$

According to this overview, the General Secretary, the National Chairman and the presidential candidate are the most prominent actors, followed by the Minority Leader in Parliament. In position 5 , we find the Regional Chairman of the Ashanti Region, which underscores the key role that Ashantis play in the NPP. The only woman, the National Women's Organiser, is found at number 6. Table IV shows the same data for the NDC network.

Two things become immediately obvious from a comparison of the two tables. For the NDC, the first two ranks are identical with those of the NPP - the National Secretary and the National Chairman are the most prominent contacts. However, the number of in-degrees in both absolute and normalised terms is extremely high for the NDC National Secretary: he is the outstanding actor in the network. Unlike the NPP, ranks three to five are also held by official national party executives, among them the National Women's Organiser. Parliamentary functionaries (namely, the Majority Leader, the Chief Whip and a prominent MP) are also very key figures, but regional functionaries are not among the top 10. Conspicuous by his absence is the president, who 


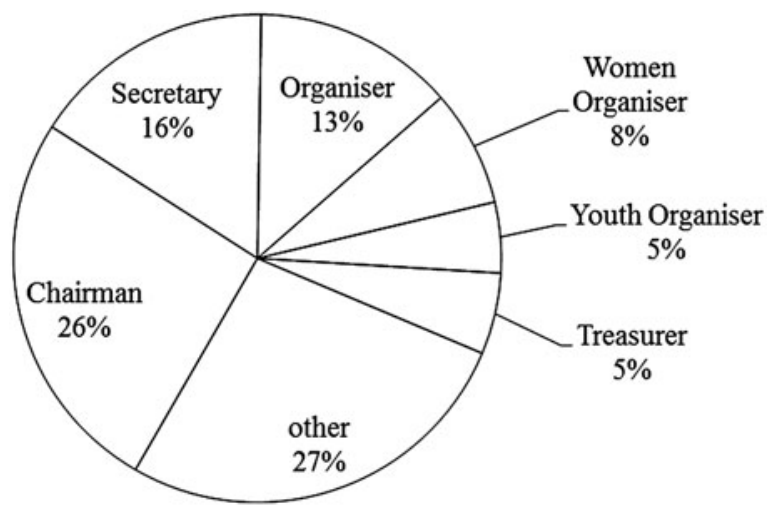

Figure ${ }_{4}$ Formal party organisation

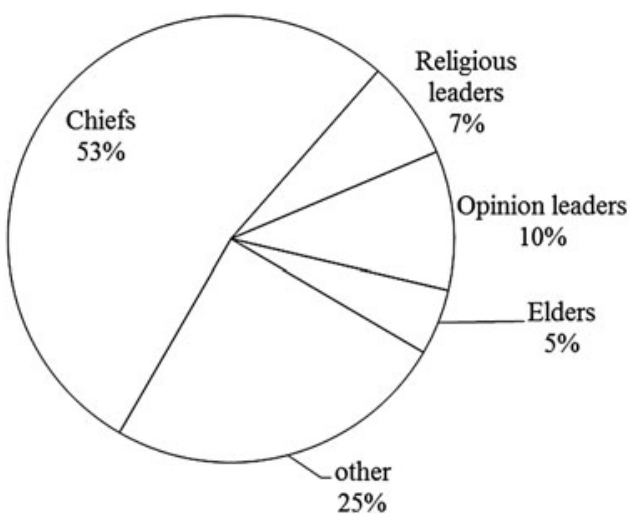

Figure 5 Informal contacts

appears only at number 17 on the list. In addition, it is notable that former President Rawlings is not a prominent figure, nor is his wife.

In the next step, clique analysis was performed to detect the underlying structure of cohesive subgroups.

Here, the differences between the parties become even more pronounced. For the NPP network, UCINET finds 31 cliques of three members each. These cliques overlap to a high degree, with only two cliques being completely isolated. The most prominent person belongs to 8 cliques. The actor-overlap structure is shown in Figure 6 . Isolates (actors who do not belong to at least one of the cliques) have been excluded from the graph. The nodes are coloured black for national executives and grey for 'others' (this category includes MPs and 


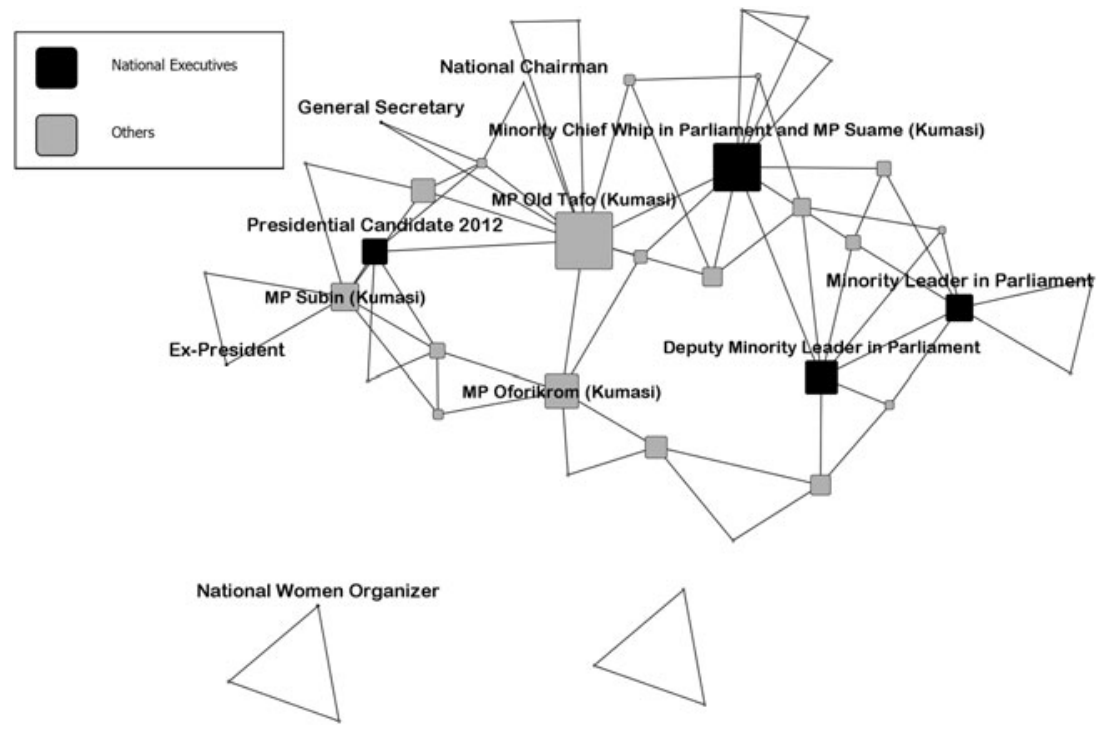

Figure 6 Actor overlap in NPP-cliques

National Executives
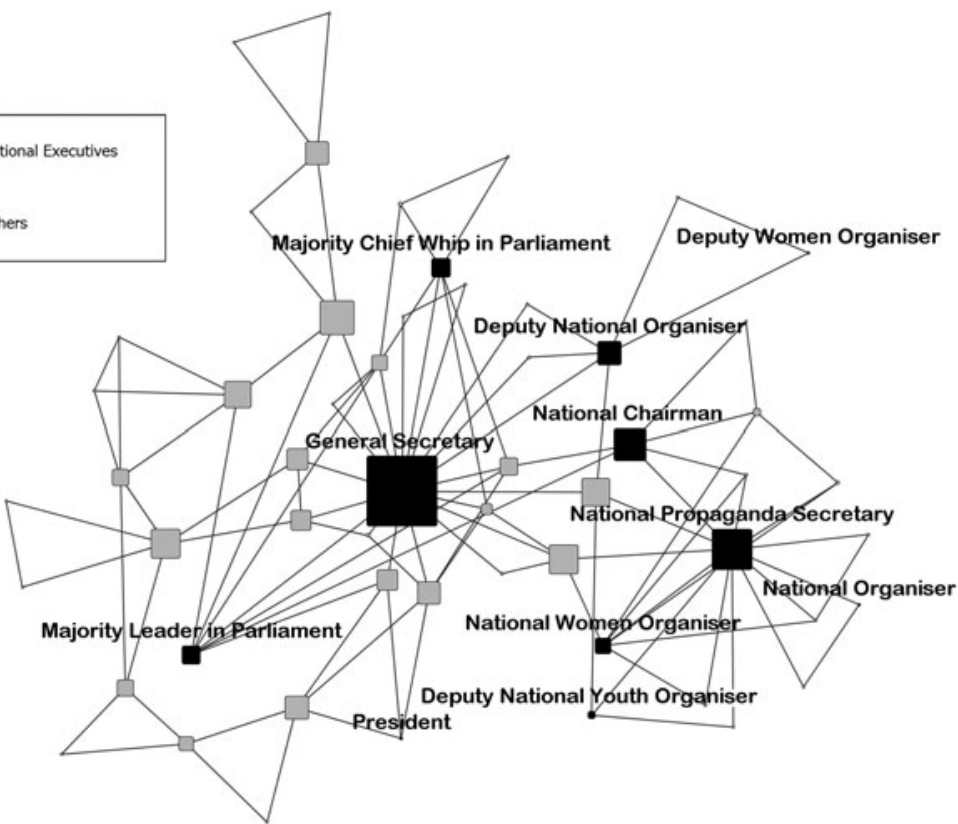

Figure 7 Actor overlap in NDC-cliques 


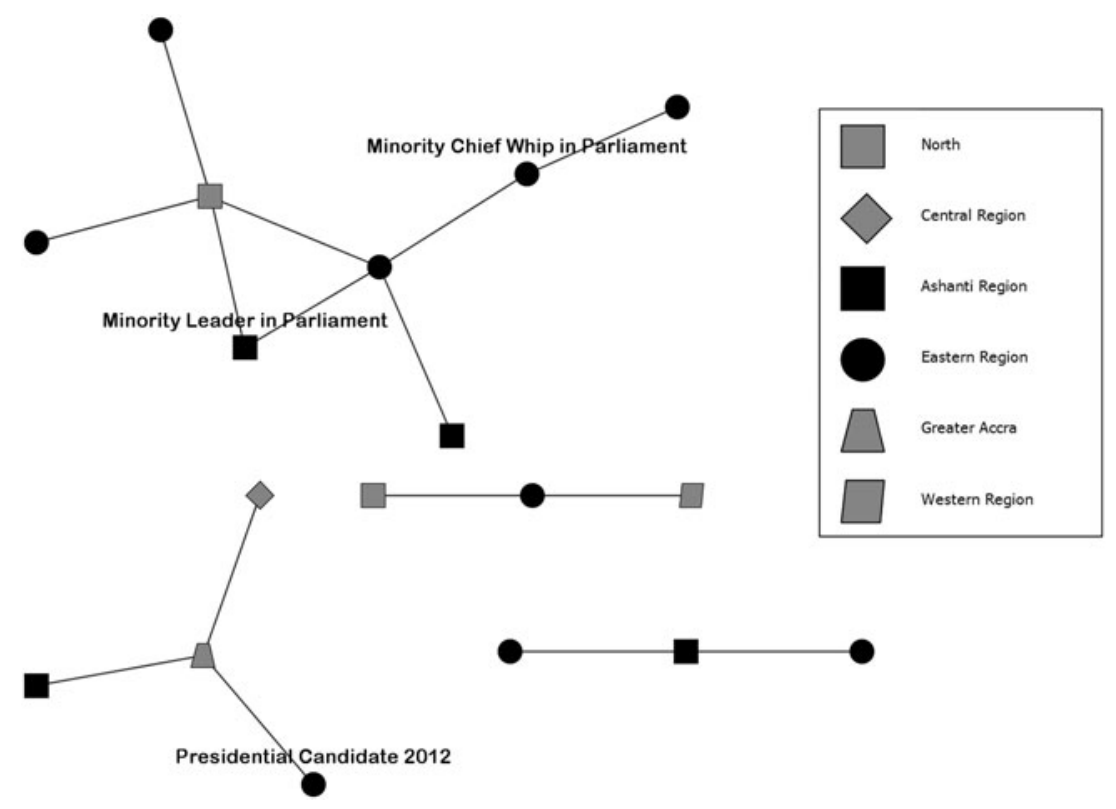

Figure 8 Regionalised factionalism NPP

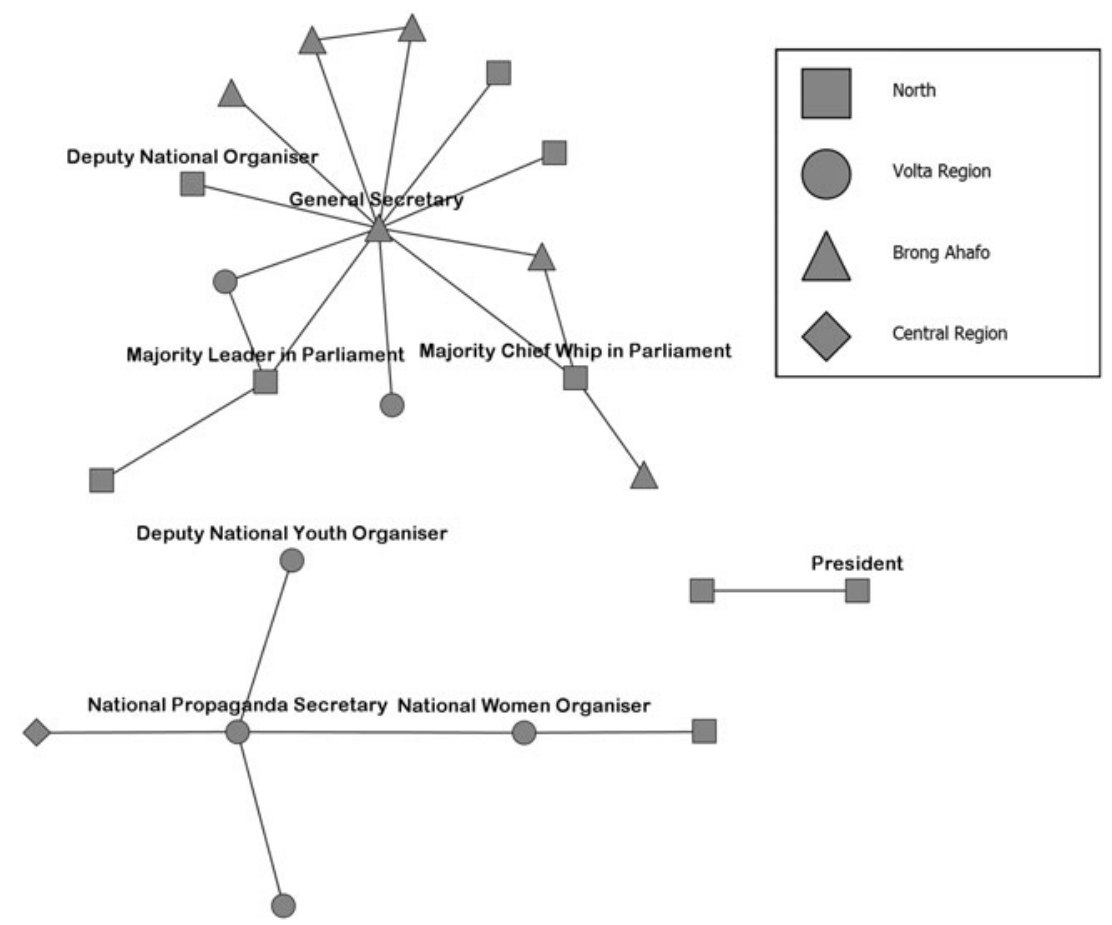

Figure 9 Regionalised factionalism NDC 
TABLE I.

Formal and informal contacts at the constituency level

\begin{tabular}{lcccc}
\hline \hline & Formal party executives & Informal contacts & Local government & $N$ \\
\hline NDC & $70 \cdot 2$ & $22 \cdot 25$ & $7 \cdot 28$ & 453 \\
NPP & $66 \cdot 86$ & $28 \cdot 24$ & $4 \cdot 9$ & 347 \\
All & $68 \cdot 22$ & $25 \cdot 64$ & $6 \cdot 13$ & 800 \\
\hline \hline
\end{tabular}

regional and local party contacts). The node size shows the betweenness score: the bigger the node, the higher the betweenness centrality of the respective actor.

There is clearly a dense and cohesive clique structure. The party executives - the General Secretary and the National Chairman - are found at the margins of the network; some parliamentary functionaries are rather central, especially the Minority Leader, his Deputy, and the Minority Chief Whip. Although these three people hold official positions and are therefore coloured black in the figure, these are parliamentary rather than party positions. It is also noteworthy that none of the three most central parliamentary leaders has a direct link to either of the two party executives. The most striking finding in this network is the fact that the Old Tafo-MP is by far the most central actor. Tafo is a neighbourhood in Kumasi situated not far from the Asantehene's palace. ${ }^{15}$ In addition, there are three other people from the Kumasi Metropolitan Area with prominent positions: the Minority Leader (who is also the MP for Suame), the MP for Subin, and the MP for Oforikrom. Their power is balanced a bit by the Minority Leader, who comes from the Eastern Region, and the Deputy Minority Leader, who is a northerner. Nevertheless, the clique analysis provides some evidence that the NPP has an informal centre of power that has close ties to the Ashanti establishment and can bypass the official party hierarchy. This perfectly fits McCaskie's (2009: 463) description of the enormous extent of Ashanti influence in the party. If betweenness centrality is interpreted as the ability to influence the flow of information or other resources in a network, then the Kumasi MPs are in a much better position than the national executives.

The situation is completely different in the NDC. UCINET finds one clique with four members and 49 cliques with three members each. In comparison to the NPP network, the NDC network is much more centralised (see Figure 7). 
TABLE II.

Relative proportion of functionaries

\begin{tabular}{lrr}
\hline \hline & NPP & NDC \\
\hline National Executives & $10 \cdot 10$ & $12 \cdot 50$ \\
Regional Executives & $9 \cdot 06$ & $6 \cdot 71$ \\
Members of Parliament & $42 \cdot 16$ & $46 \cdot 95$ \\
Local Contacts & $3^{8 \cdot 68}$ & $33 \cdot 84$ \\
\hline \hline
\end{tabular}

TABLE III .

Most central actors: NPP

\begin{tabular}{llcc}
\hline \hline Rank & Function & In-Degree & Normalised In-Degree \\
\hline 1 & General Secretary & 24 & $0 \cdot 084$ \\
2 & National Chairman & 20 & $0 \cdot 069$ \\
3 & Presidential Candidate & 20 & $0 \cdot 069$ \\
4 & Minority Leader in Parliament & 16 & $0 \cdot 05^{6}$ \\
5 & Ashanti Regional Chairman & 10 & $0 \cdot 034$ \\
6 & Women's Organiser (f) & 10 & $0 \cdot 034$ \\
7 & Minority Chief Whip & 9 & $0 \cdot 031$ \\
8 & MP & 9 & $0 \cdot 03^{1}$ \\
9 & Ashanti Regional Secretary & 8 & $0 \cdot 279$ \\
10 & Vice National Chairman & 7 & $0 \cdot 024$ \\
\hline \hline
\end{tabular}

First of all, there are no isolated cliques. Second, the central role of the party's General Secretary is striking in comparison to that of the NPP: he is in a position to effectively connect all parts of the network, and thus plays a strong role in keeping the party together. The president is a part of the cohesive substructure, but only as a minor actor. Other party executives such as the National Chairman and the National Propaganda Secretary are much more central; in addition, more national executives are part of the network. From these findings, it can be concluded that the National Executives of the NDC play a much greater role, and that there are no obvious informal power centres outside of the national party leadership. It must be borne in mind, however, that Asiedu Nketiah, the General Secretary, is an NDC-veteran. In the 1980 os, he organised youth for the first People's Defense Committee ${ }^{16}$ in his home district, was later elected to the Consultative Assembly which drafted the 1992 Constitution, and held a parliamentary seat from 1992 until 2004. ${ }^{17}$ Finally, he was elected as the NDC's General Secretary in 2005 . Therefore, Nketiah has had the time to build up a 
TABLE IV.

Most central actors: NDC

\begin{tabular}{llcc}
\hline \hline Rank & & In-degree & Normalised Degree Centrality \\
\hline 1 & General Secretary & $5^{1}$ & $0 \cdot 15^{6}$ \\
2 & National Chairman & 21 & $0 \cdot 064$ \\
3 & National Organiser & 17 & $0 \cdot 05^{1}$ \\
4 & National Propaganda Secretary & 16 & $0 \cdot 049$ \\
5 & National Women's Organiser (f) & 10 & $0 \cdot 030$ \\
6 & Majority Leader in Parliament & 9 & $0 \cdot 027$ \\
7 & MP Ablekuma South (Greater Accra) & 9 & $0 \cdot 027$ \\
8 & Majority Chief Whip & 9 & $0 \cdot 027$ \\
9 & Deputy National Organiser (f) & 8 & $0 \cdot 024$ \\
10 & Vice National Chairman & 7 & $0 \cdot 021$ \\
\hline \hline
\end{tabular}

strong personal network within the party which helped him to ascend to the position of the General Secretary. This formal position of power, in turn, allows to strengthen informal ties to fellow party members. Nketiah's position in the network is therefore the sum of formal and informal power relations.

\section{Factions}

Finally, we would like to determine whether these cliques can tell us anything about factionalism. Are actors from the same region more likely to have a relationship? In order to be able to visualise the regional origin of the actors, the networks are further modified to include only links greater than one, meaning that the networks will only show actors who are in more than one clique together (see Figure 8).

It is obvious that the Ashanti and Eastern Regions dominate the NPP network. However, there are many links between them. From these data, a strong divide between the two regions cannot be confirmed.

In the NDC, the General Secretary is situated in the centre of a star-like network that is composed of people from various regions (see Figure 9). There are, however, a striking number of people from his home region of Brong Ahafo. Of the two other disconnected networks, one consists of four people from the Volta Region, among them high party officials such as the National Propaganda Secretary and the National Women's Organiser; the other connects President Mahama to another northerner. Mahama's ego network is interestingly mono-regional, especially in contrast to most other ego networks. This holds true not only for the reduced network shown in Figure 8 but also for the entire party 
TABLE V.

QAP correlations

\begin{tabular}{lcc}
\hline \hline & $\mathrm{NPP}$ & \multicolumn{1}{c}{ NDC } \\
\hline Full network & $-\mathrm{O} \cdot 01(\mathrm{O} \cdot 0)$ & $\mathrm{O} \cdot 0 \mathrm{OO}(\mathrm{o} \cdot \mathrm{O})$ \\
Clique network & $\mathrm{O} \cdot 03(0 \cdot 03)$ & $0 \cdot 05^{* *}(\mathrm{o} \cdot 03)$ \\
Reduced clique network & $0 \cdot 04(0 \cdot 07)$ & $0 \cdot 15^{* *}(0 \cdot 07)$ \\
\hline \hline
\end{tabular}

Note: ** Significant at $5 \%$, standard errors in parentheses

\section{TABLE VI.}

Summary of findings

\begin{tabular}{|c|c|c|}
\hline & NPP & NDC \\
\hline $\begin{array}{l}\text { Constituency } \\
\text { level }\end{array}$ & $\begin{array}{l}\text { Formal and informal relationships } \\
\text { are present, formal relationships } \\
\text { predominate }\end{array}$ & $\begin{array}{l}\text { Formal and informal relationships } \\
\text { are present, formal relationships } \\
\text { predominate }\end{array}$ \\
\hline Party level & $\begin{array}{l}\text { Party executives have a comparatively } \\
\text { weak position, prominent role for } \\
\text { some MPs from Kumasi }\end{array}$ & $\begin{array}{l}\text { Party executives, especially the } \\
\text { General Secretary, have a compara- } \\
\text { tively strong position }\end{array}$ \\
\hline $\begin{array}{l}\text { Regionalised } \\
\text { factions }\end{array}$ & No & Present but relatively weak \\
\hline
\end{tabular}

network, where Mahama receives his five in-degrees exclusively from people who come from the three northern regions of Ghana.

To find out more about the significance of relationships between people from the same region, QAP correlations (described previously) were calculated at three levels: for the whole party networks, for the clique networks (the figures above), and finally for the reduced clique networks including only the actors that share membership in more than one clique. The results are shown in Table $\mathrm{V}$ below.

The QAP correlations are not significant for the NPP network at any level. In the case of the NDC, the results for both clique networks are significant, but the correlation for the clique network is extremely small. For the reduced network, the correlation is $0 \cdot 15$, which is still a relatively low value. From these data, there is no clear evidence of regionalised factionalism. There are, however, signs of a tendency for such factionalism, at least for the NDC. In particular, the fact that Mahama's ego network consists only of people from the north can be seen as an indication of this tendency. 
What can we say now about the relative importance of formal and informal relationships in the two parties? The empirical results of this paper are summarised in Table VI.

At the constituency level, there are more formal than informal contacts. It should not be hastily concluded from this that formal organisation trumps informal contacts; as has been argued above, formal and informal relationships interact in complex ways. At the very least, however, we can conclude that local party organisation matters. In addition, the data provide insight into another interesting detail: intermediary relationships with chiefs, religious leaders and DCEs play almost the same role in the two parties. This speaks to the robustness of the results: obviously, the NPP and the NDC both operate within the same context to which they are forced to adapt their strategies.

However, differences were found between the roles of the national party executives. National functionaries, and above all the General Secretary, play a much stronger role in the NDC than in the NPP. This finding is congruent with the generally united front that the NDC was able to present in the 2012 elections. There is no doubt that internal conflicts exist in both parties. According to the data collected for this paper, however, there is reason to believe that the NDC has a stronger capacity to handle these conflicts, thanks to its comparatively centralised structure of intra-party coordination. Due to their relatively marginalised positions in the network, the national executives of the NPP are much less capable of influencing the communication and decision-making processes in the party. There is also an informal power centre consisting of some of the Kumasi MPs. One very interesting observation is the differing roles of the presidential candidates and former presidents. Kufuor and Akuffo-Addo are both important figures in the NPP, integrating Ashanti and Akyem politicians. In the NDC, in contrast, the former strong man Rawlings has been completely sidelined, and President Mahama has a somewhat ambiguous position: he is part of the inner circle, but is much less prominent in comparison to Kufuor or Akuffo-Addo. Moreover, his ego network is exclusively composed of politicians from the north. This latter finding lends some credibility to the concern that internal party conflicts might arise along ethno-regional lines.

On the other hand, the existence of strong factionalism could not be proven in this paper, although this does not necessarily mean that it does not exist. As Bob-Milliar (2012) has observed, factions are constantly 
changing; it should be noted that the network data presented in this paper are effectively snapshots, capturing only a certain point in time. More work will therefore be needed to fully understand the dynamics between formal and informal politics in African parties. This paper, however, has taken a first step in this direction.

\section{NOTES}

1. In Ghana, this strategy excludes chiefs because they are not allowed to hold official functions in the political system.

2. The NDC refers to its smallest units as 'branches', the NPP as 'polling stations'.

3. In fact, the rivalry between the two groups dates back to the 18 th century. For more detail, see Fynn (1973).

4. Joseph Ayikoi Otoo, a leading member of the NPP, raised this issue in 2013. His comments have been widely reported on in the media; see, for example, 'Ayikoi Otoo warns NPP', The Chronicle, 28 October 2013, http://thechronicle.com.gh/ayikoi-otoo-warns-npp.

5. See 'Bawumia's nomination fulfils promise to Muslim community', Graphic Online, 25 October 2014 , http://graphic.com.gh/news/politics/32753-bawumia-s-nomination-fulfils-promise-to-muslimcommunity.html\#sthash.gl8vOlsF.dpuf.

6. See, for example, 'Asante Akyem Rivalry not a Problem in NPP', Myjoyonline, 28 October 2013 , http://www.myjoyonline.com/politics/2013/october-28th/asante-akyem-rivalry-not-a-problem-innpp-nyaho-tamakloe.php; and 'Sir John: Those Advancing Akyem/Ashanti Rivalry Argument only want the Downfall of NPP', Peace FM online, 29 October 2013, http://elections.peacefmonline. $\mathrm{com} /$ pages/politics/201310/178682.php?storyid=10o\&.

7. See, for example, 'Ahwois battle Mahama for control over NDC', The New Statesman, 4 June 2013, http://www.ghanaweb.com/GhanaHomePage/politics/artikel.php?ID=275968; and 'John Mahama fights Nketia - as Wrangling over Control of NDC intensifies', Peace FM online, 7 January 2014, http://elections.peacefmonline.com/pages/politics/201401/184930.php.

8. The paper is part of a wider project on the social characteristics and interaction patterns of African Members of Parliament. The questionnaire therefore included a relatively wide range of other questions that are not relevant to the research questions investigated here.

9. The question that was used reads, 'Looking back over the last six months, who are the people in your party with whom you have discussed important political decisions? Please give me their names.'

10. This might be controversial, since Mahama's network might be more narrowly structured around people with a Gonja background. The $\mathrm{N}$ for the individual ethnic groups, but also for the two very small regions Upper East and Upper West, is however relatively small. It was therefore decided to collapse the three northern regions of Ghana into one analytical unit. This is not to say that the north constitutes a homogeneous social or political space, although the north/south divide has at least some impact on Ghanaian politics (see Osei 2012: 125-6). The decision has been taken for more practical reasons, because there seems to be no other way to approach the question of a regionalised or ethnic network centred around Mahama.

11. Standard statistical procedures often make assumptions which are violated by social network data, for example about the independence of the observations or a particular distribution (see Borgatti et al. 2013: 126). To overcome these problems, special procedures like QAP correlations and QAP regressions have been developed for network data.

12. In fact, the procedure first correlates the two given matrices and calculates a measure of association. This observed correlation is then compared with the correlations between a large number of matrices which are generated by rearranging the rows and matching columns. The p-value is constructed by counting the proportion of these correlations that are as large as the observed correlation (Borgatti et al. 2013: 128).

13. Each District has its own District Assembly, which is made up of one elected Assemblyman/ woman for each local government area, the MP for the constituency, and other members who are appointed in consultation with local interest groups. The District Chief Executive (DCE) presides over the District Assembly. 
14. The normalised degree centrality is the degree divided by the maximum possible degree expressed as a percentage.

15. In fact the palace of the Asantehene is located in the constituency Manhyia South, whose MP is however not the most central person in the network. There is no easy and straightforward explanation for this. On the one hand, it could be argued that the physical closeness to the Asantehene is not directly determining someone's role in the party. A large number of intervening variables pertaining to personal characteristics of the MPs as well as party dynamics is thinkable. After all, the relationship between the NPP elite and the Ashanti aristocracy is complex and difficult to trace in a single study. An interpretation of the individual relationships of single MPs is beyond the scope of this paper. On a more general level, however, the results show very clearly that the Kumasi MPs occupy a prominent place in the party.

16. During the PNDC era, People's Defense Committees (PDCs) were created as 'instruments of popular participation, political education, channels of communication to and from the leadership, and political control' (Ray 1986: 68).

17. 'Asiedu Nketia - Astute politician', Graphic online, 18 December 2014, http://graphic.com. $\mathrm{gh} /$ news/politics/35662-profile-asiedu-nketia-astute-politician.html.

\section{R E F E R E N C E S}

Agyeman-Duah, I. 2003. Between Faith and History: a biography of J. A. Kufuor. Accra: Africa World Press. Allen, C. 1995. 'Understanding African Politics', Review of African Political Economy 22, 65: 301-20.

Appleton, A.M. \& D.S. Ward. 1995. 'Measuring party organization in the United States: an assessment and a new approach', Party Politics 1, 1: 11 13-31.

Baldwin, K. 2013. 'Why vote with the chief? Political connections and public goods provision in Zambia', American Journal of Political Science 57, 4: 794-809.

Basedau, M., G. Erdmann \& A. Mehler. 2007. 'Conclusion: the research agenda ahead', in M. Basedau, G. Erdmann \& A. Mehler, eds, Votes, Money and Violence: political parties and elections in sub-Saharan Africa. Uppsala: Nordiska Afrikainstitutet, $276-92$.

Basedau, M., G. Erdmann, J. Lay \& A. Stroh. 2011. 'Ethnicity and party preference in sub-Saharan Africa', Democratization 18, 2: 462-89.

Beck, L.J. 2008. Brokering Democracy in Africa: the rise of clientelist democracy in Senegal. Basingstoke: Palgrave Macmillan.

Bleck, J. \& N. van de Walle. 2011 . 'Parties and issues in Francophone West Africa: towards a theory of non-mobilization', Democratization 18, 5: $1125^{-45}$.

Boafo-Arthur, K. 2003. 'Political parties and democratic sustainability in Ghana, 1992-2000', in M.A. Salih, ed. African Political Parties: evolution, institutionalisation and governance. London: Pluto Press, $207-38$.

Bob-Milliar, G.M. 201 2. 'Party factions and power blocs in Ghana: a case study of power politics in the National Democratic Congress', Journal of Modern African Studies 5o, 4: 573-6o1.

Borgatti, S.P., M.G. Everett \& L.C. Freeman. 2002. UCINET for Windows: Software for Social Network Analysis. Cambridge, MA: Analytic Technologies, Harvard University Press.

Borgatti, S.P., M.G. Everett \& L.C. Freeman. 2013. Analyzing Social Networks. London: Sage.

Boucek, F. 2009. 'Rethinking factionalism: typologies, intra-party dynamics and three faces of factionalism', Party Politics 15, 4: $455^{-85}$.

Brandes, U. \& D. Wagner. 2004. 'Visone: analysis and visualization of social networks', in M. Jünger \& P. Mutzel, eds. Graph Drawing Software. Berlin: Springer, 32 1-40.

Bratton, M. 2007. 'Formal versus informal institutions in Africa', Journal of Democracy 18, 3: 36-1 10.

Bratton, M. \& N. van de Walle. 1997. Democratic Experiments in Africa: regime transitions in comparative perspective. Cambridge: Cambridge University Press.

Carothers, T. 2006. Confronting the Weakest Link: aiding political parties in new democracies. Washington, DC: Carnegie Endowment for International Peace.

Carbone, G.M. 2007. 'Political parties and party systems in Africa: themes and research perspectives', World Political Science Review 3, 3: 1-29.

Chabal, P. \& J.-P. Daloz. 1999. Africa Works: disorder as political instrument. London: James Currey.

CODEO (Coalition of Domestic Election Observers). 2005. Ghana's Election 2004. What the observers say. Accra: CDD (Center for Democratic Development) Ghana. 
Daddieh, C.K. \& G.M. Bob-Milliar. 201 2. 'In search of 'Honorable' membership: parliamentary primaries and candidate selection in Ghana', Journal of Asian and African Studies 47, 2: 204-20.

Darracq, V. 2008. 'The African National Congress (ANC) organization at the grassroots', African Affairs 107, 429: 589-6o9.

Elischer, S. 2013. Political Parties in Africa: ethnicity and party formation. New York, NY: Cambridge University Press.

Erdmann, G. 2004. 'Party research: Western European bias and the "African labyrinth", Democratization 1 1, 3: 63-87.

Erdmann, G. \& U. Engel. 2007. 'Neopatrimonialism reconsidered: critical review and elaboration of an elusive concept', Commonwealth and Comparative Politics 45, 1: $95^{-1} 19$.

Erdmann, G. \& M. Basedau. 2008. 'Party systems in Africa: problems of categorising and explaining party systems', Journal of Contemporary African Studies 26, 3: 241-58.

Fynn, J.K. 1973. 'Asante and Akyem relations, 1700-1831', African Studies Research Review 9, 1: 58-83.

Gunther, R. \& L. Diamond. 2003. 'Species of political parties: a new typology', Party Politics 9, 2: 16799.

Helmke, G. \& S. Levitsky. 2004. 'Informal institutions and comparative politics: a research agenda'. Perspectives on Politics, 4: 725-40.

Janda, K. 1983. 'Cross-national measures of party organizations and organizational theory', European Journal of Political Research 11 (3): 319-32.

Katz, R.S. \& P. Mair. 1995. 'Changing models of party organization and party democracy: the emergence of the cartel party', Party Politics 1, 1: $5^{-28}$.

Kelsall, T. 2003. 'Governance, democracy and recent political struggles in Mainland Tanzania', Commonwealth and Comparative Politics 41, 2: $55^{-82}$.

Köllner, P. \& M. Basedau. 2005. 'Factionalism in Political Parties: an analytical framework for comparative studies'. German Institute of Global and Area Studies Working Paper No. c2. Hamburg: GIGA.

Koter, D. 2013. 'King makers: local leaders and ethnic politics in Africa', World Politics 65, 2: $187-232$.

LeBas, A. 2011. From Protest to Parties: party-building and democratization in Africa. Oxford: Oxford University Press.

Lindberg, S.I. 2003. 'It's our time to 'chop': do elections in Africa feed neo-patrimonialism rather than counter-act it?', Democratization 10, 2: 121-40.

Lindberg, S.I. \& M.K.C. Morrison. 2008. 'Are African voters really ethnic or clientelistic? Survey evidence from Ghana', Political Science Quarterly 123, 1: 95-122.

McCaskie, T.C. 2009. 'Asante, Apagyafie and President Kufuor of Ghana: a historical interpretation', in T. Falola \& M.D. Childs, eds, The Changing Worlds of Atlantic Africa: essays in honor of Robin Law. Durham, NC: Carolina Academic Press, 445-77.

Misztal, B. 1999. Informality: social theory and contemporary practice. London: Routledge.

Müller, W.C. \& R.S. Katz. 1997. 'Party as linkage', European Journal of Political Research 31, 1: 169-78.

Nugent, P. 2007. 'Banknotes and symbolic capital. Ghana's elections under the Fourth Republic', in Basedau, M., G. Erdmann \& A. Mehler, eds. Votes, Money and Violence: political parties and elections in sub-Saharan Africa. Uppsala: Nordiska Afrikainstitutet, $25^{2-75}$.

Osei, A. 201 2. Party-Voter Linkage in Africa: Ghana and Senegal in comparative perspective. Wiesbaden: VS Verlag.

Osei, A. 2013. 'Party system institutionalisation in Ghana and Senegal', Journal of Asian and African Studies 48, 5: 577-93.

Pitcher, M.A. 201 2. Party Politics and Economic Reform in Africa's Democracies. New York, NY: Cambridge University Press.

Ray, D.I. 1986. Ghana: politics, economics, and society. London: Pinter.

Riedl, R.B. 2014. Authoritarian Origins of Democratic Party Systems in Africa. New York, NY: Cambridge University Press.

Sartori, G. 2005. 'Party types, organisation and functions', West European Politics 28(1): 5-32.

Zariski, R. 1960. 'Party factions and comparative politics: some preliminary observations', Midwest Journal of Political Science 4, 1: 27-51. 